\title{
AKIBAT HUKUM PEMBATALAN PERJANJIAN BOT (BUILD OPERATE TRANSFER) YANG DIBATALKAN SECARA SEPIHAK OLEH PEMEGANG HAK ATAS TANAH (STUDI KASUS : PUTUSAN No. 97/PK/PDT/2017)
}

\author{
Vanny Aryanti \\ (Mahasiswa Program S1 Fakultas Hukum Universitas Tarumanagara) \\ (E-mail: vannyaryanti21@ gmail.com)
}

\begin{abstract}
Siti Nurbaiti
(Coresponding Author)

(Dosen Hukum Perdata Fakultas Hukum Universitas Tarumanagara, Meraih Sarjana Hukum dari Fakultas Hukum Universitas Tarumanagara, Magister Hukum dari Fakultas Hukum Universitas Trisakti, Doktor Hukum dari Fakultas Hukum Universitas Tarumanagara)
\end{abstract}

\begin{abstract}
The investment activity has grown up rapidly in Indonesia. Indonesia needs to do some infrastructure developments. The goverments offers one of the investment to their people, in form of Build Operate Transfer Contract. Under a Build Operate Transfer Contract, an entity ussually a goverment grants a concenssion to a private company to finance, build, and operate a project. The private company usually operates the project for a time periode with the goal of recouping its investment, then transfers control of the project to the goverment. In Fact some contracts has been cancelled by one side, the landlord. One of them is the contract between PT Sarana Pembangunan Palembang Jaya and PT Tradeways International. The landlord accuses the investor to do his obligations without good intentions.This research method is normative. Impact form tort whose done by the landlord with using secondary data source and primary, secondary, and tertiary legal source. However, the cancellation of the contract by one side has not fulfilled all the elements that is containin Article 1266 Indonesian Civil Code. The consequences behind that is the landlord must pay the compensations.
\end{abstract}

Keywords : Build Operate Transfer Contract, cancelled by one side, landlord 


\section{Pendahuluan}

\section{A. Latar Belakang}

Kegiatan investasi berkembang dengan sangat pesat di dalam masyarakat saat ini. Adanya kebutuhan akan pembangunan infrastruktur di Indonesia saat ini maka pemerintah membutuhkan peranan dari pihak swasta untuk ikut andil dalam bagian pembangunan infrastruktur saat ini yang membutuhkan biaya yang sangat besar karena keterbatasan APBN. Sehingga pemerintah gencar memberikan tawaran kepada masyarakat ataupun pihak swasta ataupun perorangan yang mempunyai modal besar yang ingin melakukan kegiatan investasi dalam bentuk infrastruktur di atas asset atau kekayaan negara terutama di atas tanah negara.

Meskipun Perjanjian Bangun Guna Serah (Build Operate Transfer/BOT) merupakan istilah yang relatif baru dalam kegiatan ekonomi Indonesia, tetapi jika melihat sejarahnya konsep BOT sebenarnya konsep BOT sudah memiliki umur yang cukup tua yaitu sekitar 300 Sebelum Masehi yang dilakukan di Kota Eretria Yunani (Athena). ${ }^{1)}$

Kontrak antara instansi pemerintahan dan badan usaha/swasta (special purpose company) dalam membangun infrastruktur publik yang bertujuan untuk meningkatkan pertumbuhan infrastruktur tanpa pengeluaran dana dari pemerintah, dimana pihak swasta bertanggung jawab atas desain akhir, pembiayaan, kontruksi, operasi, dan pemeliharaan sebuah proyek investasi bidang infrastruktur selama beberapa tahun, biasanya dengan transfer atau penyerahan aset pada masa akhir kontrak yang bertujuan untuk melaksanakan pembangunan demi kepentingan umum sehingga adanya pemberian pelayanan publik dari pemerintah kepada masyarakat. Apabila telah disepakati maka para pihak wajib untuk melaksanakan kewajiban masing-masing yang tercantum dalam isi perjanjian karena dengan adanya kesepakatan maka timbul hubungan hukum antara pemegang hak atas tanah dengan pihak investor.

\footnotetext{
${ }^{1)}$ Munir Fuady, Sejarah Hukum, (Bogor: Ghalia Indonesia 1982),172.
} 
Ciri proyek build operate transfer adalah adanya pembangunan (build), adanya pengoperasian (operate), dan adanya penyerahan kembali (transfer). Perjanjian Build operate transfer dalam peraturan perundangan Indonesia lebih dikenal dengan perjanjian bangun guna serah (BGS) yang definisinya dapat ditemukan di Keputusan Menteri Keuangan RI No. 248/KMK.04/1995 tentang Perlakuan Pajak Penghasilan terhadap PihakPihak yang Melakukan Kerja Sama dalam Bentuk Perjanjian Bangun Guna Serah dan di dalam Peraturan Menteri Dalam Negeri Republik Indonesia No. 19 tahun 2016 tentang Pedoman Pengelolaan Barang Milik Daerah.

Pengertian perjanjian BOT(build operate transfer) atau yang selanjutnya disebut bangun guna serah definisnya dapat dilihat di dalam Peraturan Menteri Dalam Negeri Republik Indonesia Nomor 19 tahun 2016 tentang Pedoman Pengelolaan Barang Milik Daerah Bab 1 butir (36)menyatakan Bangun Guna Serah yang selanjutnya disingkat BGS adalah Pemanfaatan barang milik daerah berupa tanah oleh pihak lain dengan cara mendirikan bangunan dan/atau sarana berikut fasilitasnya, kemudian didayagunakan oleh pihak lain tersebut dalam jangka waktu tertentu yang telah disepakati, untuk selanjutnya diserahkan kembali tanah beserta bangunan dan/atau sarana berikut fasilitasnya setelah berakhirnya jangka waktu. $^{2)}$

Pengertian perjanjian BOT (build operate transfer) atau yang selanjutnya disebut bangun guna serah definisi lainnya dapat ditemukan di dalam Peraturan Menteri Dalam Negeri Republik Indonesia Nomor 19 tahun 2016 tentang Pedoman Pengelolaan Barang Milik Daerah Bab 1 butir (37) menyatakan Bangun Guna Serah atau yang selanjutnya disebut BGS adalah pemanfaatan barang milik daerah berupa tanah oleh pihak lain dengan cara mendirikan bangunan dan/atau sarana berikut fasilitasnya, dan setelah selesai pembangunannya diserahkan untuk didayagunakan oleh pihak lain

\footnotetext{
${ }^{2)}$ Indonesia, Peraturan Menteri Dalam Negeri Republik Indonesia Nomor 19 tahun 2016 tentang Pedoman Pengelolaan Barang Milik Daerah, Bab 1 butir 36.
} 
tersebut dalam jangka waktu tertentu yang disepakati." ${ }^{, 3)}$ Sehingga dari definisi di atas dapat disimpulkan BOT merupakan perjanjian kerjasama antara pemilik modal (investor) dengan dengan penyedia asset berupa lahan yang selanjutnya dikelola oleh pihak investor.

Berdasarkan Keputusan Menteri Keuangan RI Nomor 248/KMK.04/1995 tentang Perlakuan Pajak Penghasilan terhadap Pihak Pihak yang Melakukan Kerjasama dalam Bentuk Perjanjian Bangun Guna Serah (BOT) Pasal (1), definisi BOT adalah Bentuk perjanjian kerjasama yang dilakukan antara pemegang hak atas tanah dengan investor, yang menyatakan bahwa pemegang hak atas tanah memberikan hak kepada investor untuk mendirikan bangunan selama masa perjanjian bangun guna serah (BOT), dan mengalihkan kepemilikan bangunan tersebut kepada pemegang hak atas tanah selama masa bangun guna serah berakhir." ${ }^{, 4)}$ Sehingga dapat disimpulkan bahwa pihak-pihak yang terikat perjanjian build operate transferpada awal perkembangannya hanya antara pihak pemerintah baik di pusat maupun di daerah dengan pihak swasta tetapi, dewasa ini model perjanjian build operate transfer juga mulai dipakai oleh pemegang hak atas tanah (swasta) dengan pemilik modal (swasta). Dalam dunia bisnis, yang mempertemukan para pelakunya dalam aktivitas bisnis, kontrak merupakan instrumen yang penting dan senantiasa membingkai hubungan hukum dan mengamankan transaksi di antara mereka. ${ }^{5)}$

Perlindungan hukum dalam perjanjian build operate transfer belum diatur secara khusus dalam suatu undang-undang tetapi perjanjian

\footnotetext{
${ }^{3)}$ Indonesia, Peraturan Menteri Dalam Negri Republik Indonesia Nomor 19 tahun 2016 tentang Pedoman Pengelolaan Barang Milik Daerah, Bab 1 butir 37.

${ }^{4)}$ Indonesia, KeputusanMenteri Keuangan RI Nomor 248/KMK.04/1995 tentang Perlakuan Pajak Penghasilan terhadap Pihak Pihak yang Melakukan Kerjasama dalam Bentuk Perjanjian Bangun Guna Serah (BOT), Pasal 1.

${ }^{5)}$ Moch. Isnaeni, "Perkembangan Hukum Perdata di Indonesia," Asas Proposionalitas dalam Kontrak Bisnis, ed. Agus Yudha Hernako(Yogyakarta: Laksbang Grafika, 2013),53.
} 
BOT merupakan salah satu bentuk hukum yang dibuat sendiri oleh para pihak dan dipersamakan dengan undang-undang karena buku III KUHPer menganut sistem terbuka (open system), artinya para pihak bebas untuk mengadakan kontrak dengan siapa pun, menentukan syarat-syaratnya, pelaksanaanya, dan bentuk kontrak, baik berbentuk lisan maupun tertulis. Selain itu kita diperkenankan untuk membuat kontrak, baik yang telah dikenal dalam KUHper maupun di luar KUHPer. Kontrak yang timbul, tumbuh, dan berkembang di dalam praktik disebut sebagai kontrak inominaat.

Perjanjian build operate transfer tetap mengacu pada asas-asas perjanjian dalam KUHPer salah satunya adalah asas kebebasan berkontrak asalkan tidak bertentangan dengan peraturan perundang-undangan yang ada, ketertiban umum, dan kesusilaan yang ada dalam masyarakat.

Sebagaimana diketahui, kemitraan yang dijalin pemerintah dengan pihak swasta dalam bentuk kontrak kerjasama merupakan sebuah hubungan hukum yang terjadi di antar kedua belah pihak. Hal yang diperjanjikan dalam kontrak tersebut bersifat privat, mengikat keduanya secara khusus sesuai dengan hal yang diperjanjikan. Sepanjang kontrak tersebut tidak bertentangan dengan syarat sahnya perjanjian, maka kontrak itu sah menurut hukum. Di dalam Pasal 1338 ayat (1) KUHPer disebutkan bahwa suatu perjanjian yang dibuat sah berlaku sebagai undang-undang bagi mereka yang membuatnya. Ketentuan ini menggarisbawahi bahwa perjanjian antar dua pihak bersifat privat. Untuk itulah pemerintah melakukan hubungan kontraktual meskipun di dalamnya selalu membawa nuansa bagian hukum berdasarkan hukum privat dan hukum publik namun, perjanjian yang dibuatnya masuk ke dalam ranah privat.

Efektifitas pembangunan infrastruktur yang dilakukan oleh pemerintah dengan menggunakan sistem BOT cukup berhasil. Hal tersebut dapat dilihat bahwa pemerintah tidak perlu mengeluarkan uang atau likuiditas APBN dalam jumlah besar untuk melakukan pembangunan sarana dan prasarana. Sehingga pembangunan dapat dilakukan dengan maksimal 
tanpa harus membayar investor untuk pembangunan yang telah dilakukan. Faktor lain berkembangnya perjanjian BOT di perkotaan besar dengan memanfaatkan lahan milik pemerintah yaitu karena persediaan lahan yang semakin terbatas dan tingkat kebutuhan lahan yang semakin meningkat maka salah satu alternatif untuk memenuhi kebutuhan lahan tersebut yaitu memnafaatkan lahan pemerintah yang kosong karena terbatasnya dana pemerintah untuk mengelola lahan tersebut sehingga dengan adanya perjanjian BOT kedua belah pihak akan saling diuntungkan.

Model perjanjian BOT juga digunakan oleh perusahaan swasta yang ingin menanamkan modalnya ke atas tanah pemegang hak atas tanah (swasta)dalam rangka memperluas bisnis mereka. Pihak investor tidak perlu membeli sebidang tanah dengan jumlah mahal tetapi, dengan perjanjian BOT akan memberikan suatu efesiensi biaya pada perusahaan mereka. Perjanjian ini dilakukan dengan dasar asas kerja sama yang saling menguntungkan, tetapi dalam prakteknya banyak sekali terjadi pembatalan perjanjian oleh pihak pemegang hak atas tanah ketika investasi telah berjalan.

Salah satu contoh kasus mengenai pembatalan perjanjian secara sepihak terdapat pada Putusan No. 97/PK/PDT/2017 antara PT Sarana Pembangunan Palembang Jaya vs PT Tradeways International, yang mana perjanjian BOT No 041/SP2J/SPK/V/2011 tanggal 16 Mei 2011 untuk melakukan pengelolaan Kawasan Taman Kambang Iwak Besak di Palembang yang terletak di Jalan Tasik Kelurahan Talang Semut, Kecamatan Bukit Kecil, Kota Palembang. Secara tiba-tiba perjanjian tersebut dibatalkan secara pihak oleh PT Sarana Pembangunan Palembang Jaya. Kasus ini terjadi karena perjanjian BOT yang mengatur hubungan hukum kedua belah pihak tidak diatur secara detail mengenai tata cara pemutusan hubungan hukum kedua belah pihak. Sehingga PT Sarana Pembangunan Palembang Jaya melakukan pembatalan perjanjian dengan dasar bahwa PT Tradeways Internasional telah melakukan wanprestasi perjanjian karena proses pembangunan terkesan terbengkalai. Atas dasar 
tersebut kemudian PT Tradeways Internasional mengajukan gugatan meminta ganti kerugian terhadap semua investasi yang telah dikeluarkan untuk Kawasan Iwak Kambang.

Uraian di atas, maka kemungkinan bahwa konflik yang timbul di kemudian hari adalah dapat berupa wanprestasi ataupun perbuatan melawan hukum. Apabila dibiarkan berlarut-larut dapat berujung pada pemutusan hubungan hukum. Namun mengingat pembatalan pihak dilakukan secara sepihak maka menjadi suatu persoalan hukum yang cukup rumit, apalagi bila dalam perjanjian tidak mengatur secara detail mengenai antisipasi permasalahan hukum yang timbul.

Contoh kasus tersebut tentu sangat merugikan para investor yang telah menanamkan modal mereka di atas tanah pemegang hak atas tanah. Melihat dari permasalahan di atas tentunya investor seharusnya lebih selektif terhadap isi dari perjanjian yang telah disepakati oleh kedua belah pihak. Berdasarkan uraian di atas, maka judul penelitian ini adalah"Akibat Hukum Pembatalan Perjanjian BOT (Build Operate Transfer) yang Dibatalkan secara Sepihak oleh Pemegang Hak Atas Tanah (Studi Kasus : Putusan No. 97/PK/PDT/2017)".

\section{B. Perumusan Masalah}

Berdasarkan latar belakang yang telah diuraikanmaka permasalahan hukum yang diambil untuk penulisan ini yaitu bagamainakah akibat hukum putusan No. 97 PK/Pdt/2017 terhadap pembatalan perjanjian BOT (Build Operate Transfer) secara sepihak?

\section{MetodePenelitian}

\section{Jenis Penelitian}


Jenis penelitian yang digunakan dalam penelitian ini adalah penelitian jenis penelitian normatif yaitu penelitian yang mengacu pada norma-norma hukum yang terdapat dalam peraturan perundangundangan yaitu berdasarkan norma-norma yang telah ada dalam masyarakat sebagaimana idealnya suatu hal yang telah diatur dalam undang-undang. ${ }^{6}$ Dalam hal ini yang telah diatur yaitu mengenai tata cara pembatalan perjanjian seperti yang telah diatur dalam KUHPer.

2. Jenis dan sumber data

Jenis data yang digunakan dalam penelitian ini adalah jenis data sekunder, ${ }^{7)}$ dimana sumber data yang digunakan dalam penelitian ini yaitu sumber data kepustakaan berupa buku, artikel, peraturan perundang-undangan dan sumber data kepustakaan lainnya.

Jenis bahan hukum yang digunakan adalah bahan hukum primer, sekunder dan tertier. ${ }^{8)}$

a. Bahan hukum primer adalah bahan-bahan yang isinya mempunyai kekuatan mengikat kepada masyarakat. Terkait dengan permasalahan yang dibahas bahan hukum primer yang penulis pakai adalah Kitab Undang-Undang Hukum Perdata (KUHPdt), Peraturan Menteri Keuangan RI No. 248/KMK.04/1995 tentang Perlakuan Pajak Penghasilan terhadap Pihak-Pihak yang Melakukan Kerja Sama dalam Bentuk Perjanjian Bangun Guna Serah, dan Peraturan Menteri Dalam Negeri Republik Indonesia No. 19 tahun 2016 tentang Pedoman Pengelolaan Barang Milik Daerah.

b. Bahan hukum sekunder adalah bahan hukum yang isinya memberikan informasi mengenai bahan hukum primer. Dalam hal ini bahan hukum sekunder yang dimaksud adalah jurnal-jurnal, makalah-makalah maupun buku-buku yang berhubungan dengan pembatalan suatu perjanjian.

\footnotetext{
${ }^{6)}$ Soerjono Soekanto dan Sri Mamudji (2), Penelitian Hukum Normatif, Cetakan ke-7, (Jakarta: Raja Grafindo Persada, 2004), 10.

${ }^{7)}$ Ibid., 24.

${ }^{8)}$ Ibid., 33.
} 
c. Bahan hukum tertier, yakni bahan yang memberikan petunjuk maupun penjelasan terhadap bahan hukum primer dan sekunder. Dalam hal ini bahan hukum tertier yang digunakan penulis adalah kamus-kamus hukum.

3. Pendekatan Penelitian

Pendekatan yang dipakai adalah pendekatan undang-undang (statute approach) dilakukan dengan menelaah undang-undang dan regulasi yang bersangkut paut dengan isu hukum yang sedang ditangani. ${ }^{9)} \mathrm{Jadi}$ peraturan perundang-undangan yang berlaku dan berkaitan dengan permasalahan yang diteliti yaitu peraturan mengenai perjanjian, perjanjian BOT dan mengenai pembatalan perjanjian.

4. Spesifikasi Penelitian

Spesifikasi penelitian yang digunakan adalah suatu proses untuk menemukan aturan hukum, prinsip-prinsip hukum, maupun doktrin hukum guna menjawab isu hukum yang dihadapi. Hal ini sesuai dengan karakter preskriptif ilmu hukum. ${ }^{10)}$ Penelitian ini akan membahas spesifik mengenai uraian tentang perlindungan hukum terhadap investor yang perjanjiannya dibatalkan sepihak oleh pihak pemegang hak atas tanah.

\section{Teknik Analisis Data}

Teknik analisis data yang digunakan dalam penelitian ini adalah deduktif yaitu bertolak dari suatu proposisi umum yang kebenarannya telah diketahui (diyakini) dan berakhir pada suatu kesimpulan (pengetahuan baru) yang bersifat lebih khusus. ${ }^{11}$ Proses penalaran dari satu atau lebih pernyataan umum (premis) untuk mencapai kesimpulan logis tertentu. Sehingga disiniakan ditelaah peraturan perundang-undangan yang berkaitan dengan permasalahan

\footnotetext{
${ }^{9)}$ Peter Mahmud Marzuki, Penelitian Hukum, Cetakan ke-4, (Jakarta : Kencana Prenanda Media Group,2008), 93.

${ }^{10)}$ Ibid., 35 .

${ }^{11)}$ Bambang Sunggono, Metodologi Penelitian Hukum, Cetakan ke-6. (Jakarta: RajaGrafindo Persada, 2003), 11.
} 
mengenai perjanjian BOT terutama mengenai permasalahan banyaknya perjanjian yang diputus secara sepihak oleh pemegang hak atas tanah.

Analisa hanya dilakukan terhadap pasal-pasal yang isinya merupakan kaedah (hukum). Setelah dilakukan analisa, maka konstruksi dilaksanakan dengan cara memasukan pasal-pasal tertentu, ke dalam kategori-kategori atas dasar pengertian-pengertian dasar dari sistem hukum tersebut. ${ }^{12)}$

\section{Pembahasan}

Untuk menjawab permasalahan ini penulis menggunakan KUHPer dan Pasal-Pasal yang terdapat di dalam putusan pengadilan nomor 97/PK/Pdt/2017. Perjanjian BOT termasuk ke dalam perikatan yang lahir dari perbuatan seseorang karena adanya kehedak para pihak karena berdasarkan KUHPerdata suatu perikatan dapat lahir dari 2 sebab. Perikatan yang lahir dari perjanjian biasanya mempunyai empat unsur, dalam kasus ini 4 unsur tersebut telah terpenuhi yaitu adanya hubungan hukum kedua belah pihak setelah perjanjian secara sah ditandatangani kedua belah pihak, bersifat harta kekayaan atau adanya suatu nilai komersil dalam hubungan hukum tersebut, adanya subjek hukum yaitu PT Tradeways Internasional dan PT Sarana Pembangunan Palembang Jaya, dan adanya kewajiban yang harus dilaksanakan kedua belah pihak sesuai dengan isi dari perjanjian tersebut.

Pasal 1338 KUHPer bahwa "semua perjanjian yang dibuat secara sah berlaku sebagai Undang-Undang bagi mereka yang membuatnya". Artinya bahwa apabila semua syarat-syarat yang terdapat dalam Pasal 1320 KUHPer terpenuhi maka syarat sahnya perjanjian telah terpenuhi sebagaimana yang diatur dalam KUHPer. Suatu perjanjian di dalam dunia bisnis juga dibuat agar adanya suatu kepastian hukum di kedua belah pihak. Sehingga para pihak dalam membuat perjanjian seolah-olah membuat perjanjian bagi mereka sendiri

\footnotetext{
${ }^{12)}$ Soerjono, Op.Cit., 255.
} 
sesuai dengan kepentingan masing-masing. Atau dengan kata lain perjanjian hanya meletakkan kewajiban bagi para pihak yang ada di dalam perjanjian sedangkan pihak ketiga diluar perjanjian tidak dapat mengikatkan diri kecuali diatur sendiri dalam perjanjian tersebut sesuai dengan Pasal 1315 KUHPer.

Perjanjian yang dilakukan oleh investor dan pemegang hak atas tanah merupakan perjanjian timbal balik sehingga para pihak menganut asas kebebasan berkontrak untuk menentukan bentuk dan isi jenis perjanjian meliputi hak dan kewajiban masing-masing yang sesuai dengan kemampuan masing-masing dalam menjalankannya. Bahkan di dalam asas kebebasan berkontrak seseorang dapat memperjanjikan bahwa ia dapat harus bertanggungjawab terhadap kerugian tertentu yang timbul karena kelalaian atau kesengajaannya (terbatas pada hal-hal tertentu yang diperjanjikan). Sehingga suatu pelanggaran perjanjian yang dilakukan oleh salah satu pihak. Karena isi dari perjanjian itu mereka tentukan sendiri maka pada akhirnya pihak-pihak dalam perjanjian terikat pada janji yang yang diberikan kepada pihak lain dan sebaliknya. Jadi orang terikat dalam suatu perjanjian bukan karena paksaan tetapi karena kehendak sendiri secara sukarela karena merasa sanggup untuk melakukan kewajiban tersebut. Tetapi konsep kebebasan berkontrak juga memiliki batasan yang diatur dalam Pasal 1337 KUHPer yaitu "perjanjian tidak boleh bertentangan dengan kesusilaan, ketertiban umum, dan Undangundang."YYang dimaksud dari Pasal 1337 KUHPer tersebut adalah antara para pihak-pihak yang membuat perjanjian tidak boleh misalnya memperjanjikan mengenai sesuatu yang dilarang seperti narkoba, menjual manusia, dll. Sehingga dapat disimpulkan bahwa perjanjian BOT yang dibuat oleh kedua belah pihak dalam perjanjian ini dibuat berdasarkan asas kebebasan berkontrak tapi tidak bertentangan dengan 1337 KUHPer karena yang diperjanjikan kedua belah pihak mengenai sesuatu yang halal dan tidak bertentangan.

Asas kebebasan berkontrak ini juga dapat menentukan pilihan untuk menentukan siapa pemanfaat tanah yang akan melakukan investasi dan memanfaatkan lokasi strategi Taman Iwak Kambang untuk digunakan secara komersiil, serta untuk menggerakan roda perekonomian daerah agar dapat 
menarik minat wisatawan untuk berkunjung Taman Kambang Iwak Besak dan agar dapat meningkatkan penghasilan pendapatan Pemerintah Kota Palembang.

Pasal 1338 ayat (2) mengatur bahwa janji itu mengikat sehingga para pihak tidak dapat menarik diri dari akibat-akibat perjanjian yang dibuatnya secara sepihak. Secara sepihak artinya tidak adanya kesepakatan di pihak lainnya tetapi dapat ditafsirkan bahwa perjanjian dapat dibatalkan apabila ada kesepakatan di kedua belah pihak. Dan secara umum pembatalan perjanjian harus ada putusan pengadilan telebih dahulu sebagaimana yang diatur dalam Pasal 1266 KUHPer kecuali di dalam perjanjian para pihak dapat memintakan pengakhiran perjanjian tanpa putusan pengadilan dengan klausula khusus yang definisinya tertulis secara rinci agar apabila di kemudian hari terjadi suatu permasalahan tidak sampai menimbulkan suatu hubungan yang buruk di antara kedua belah pihak yang ada dalam perjanjian tetapi dalam putusan disebutkan bahwa di dalam perjanjian tidak ada klausula yang mengatur secara khsusus mengenai hal tersebut. Pasal 1266 KUHPer juga mengatur bahwa setiap perjanjian tidak batal demi hukum maka harus dimintakan pembatalannya kepada hakim. Karena tidak ada klausula yang mengatur perjanjian seharusnya pihak pemegang hak atas tanah memintakan pembatalan perjanjian lewat hakim bukan melalui surat yang dikeluarkannya sendiri. Di beberapa klausula perjanjian yang dijadikan dasar pemutusan hubungan kerjasama memang banyak tertulis bahwa untuk hal-hal tertentu harus ada persetujuan dari pihak pemegang hak atas tanah tetapi tidak ditulis lebih lanjut bahwa jika tidak ada persetujuan dari pihak pemegang hak atas tanah maka konsekuensi hukum apa yang akan didapat.

Pengertian kesepakatan bahwa Undang-Undang tidak memberikan suatu definisi mengenai arti kesepakatan, akan tetapi timbulnya kesepakatan dapat dikaji dengan pendekatan teori-teori yang ada dan berkembang hingga saat ini. Kesepakatan memiliki dua unsur, yaitu unsur penawaran (offer) dan unsur penerimaan (acceptance). Saat bertemunya penawaran dan pemnerimaan itulah yang dapat dikatakan sebagai saat terjadinya suatu kesepakatan antara 
para pihak sehingga melahirkan suatu perjanjian. ${ }^{13)}$ Seserorang yang melakukan penawaran kepada orang lain maka telah menawarkan suatu hak kepada orang lain dan kemudian tergantung pada orang tersebut untuk menerima atau menolak hak yang telah ditawarkan tersebut. Jika hak yang ditawarkan tersebut diterima oleh pihak lawan maka dapat dikatakan telah terjadi suatu kesepakatan. Yang dapat disimpulkan bahwa kesepakatan itu adalah pertemuan kehendak antara pihak penawar dengan pihak lawan karena telah menyetujui hak yang ditawarkan oleh pihak penawar. Sedangkan kesepakatan menjadi tidak berlaku apabila telah terjadi suatu penolakan terhadap hak yang ditawarkan. Dalam hal ini menurut penulis antara kedua belah pihak yang berselisih telah terjadi suatu kesepakatan karena perjanjian tersebut sudah berjalan satu tahun dan kemudian baru timbul suatu permasalahan. Tetapi untuk menemukan kapan saat terjadinya kesepakatan tidak selalu mudah. Karena apabila terjadi kesalahan dalam menentukan kapan terjadinya kesepakatan maka hak tersebut dapat menyebabkan akibat hukum yaitu pembatalan suatu perjanjian. Dan asas konsensualisme ini tetap harus memenuhi syarat-syarat yang ada dalam Pasal 1320 KUHPer.

Asas itikad baik dalam hal ini menurut penulis juga terpenuhi dalam perjanjian BOT ini karena perjanjian sudah berjalan satu tahun hingga kemudian menurut penulis tidak adanya itikad baik dari kedua belah pihak untuk menyelesaikan masalah secara musyawarah mufakat sehingga menyebabkan pihak BUMD dengan itikad tidak baik memutuskan perjanjian secara sepihak padahal di dalam perjanjian tidak diatur secara tegas bagaimana tata cara pemutusan hubungan perjanjian kerjasamanya sehingga pembatalan perjanjian yang dilakukan menjadi suatu perbuatan melawan hukum dan berakibat hukum harus adanya kewajiban dari pihak pemegang hak atas tanah untuk membayar ganti kerugian. Tetapi di pihak lain kita juga harus melihat apakah pihak investor juga memiliki itikad baik untuk melaksanakan perjanjian yang telah ia buat. Dalam undang-undang tidak dijelaskan apa yang dimaksud

${ }^{13)}$ Irawan Soerodjo, Hukum Perjanjian dan Pertanahan Perjanjian Build, Operate, and Transfer (BOT) atas tanah Pengaturan, Karakteristik, dan Praktik, Cetakan ke -2, (Yogyakarta: Laksbang PRESSindo 2017), 26. 
dengan itikad baik, kecuali dalam Pasal 1338 ayat (3) KUHPer, disebutkan bahwa : "Perjanjian harus dilaksanakan dengan itikad baik". Sebenarnya itikad baik yang disebut dalam Bahasa Belanda dengan tegoedertrouw, yang sering juga diterjemahkan dengan kejujuran, dapat dibedakan menjadi 2 macam, yaitu (1) itikad baik pada waktu mengadakan perjanjian; dan (2) itikad baik pada waktu melaksanakan hak-hak dan kewajiban yang timbul dari perjanjian tersebut. ${ }^{14)}$ menurut kajian penulis pada saat perjanjian dibuat telah memenuhi asas itikad baik akan tetapi pada pelaksanaannya yang baru berjalan 1 (satu) tahun pihak pemegang hak atas tanah dengan itikad tidak baik membatalkan perjanjian secara sepihak dapat digolongkan sebagai itikad tidak baik pada waktu melaksanakan hak-hak dan kewajiban yang timbul dari perjanjian tersebut. Pernyataan ini pun juga diperkuat dengan data wawancara dengan Bapak Hanafi Tanuwidjaja, S.H., M.H bahwa hal ini berkaitan erat dengan itikad baik pada saat perjanjian itu dibuat. Dan perjanjian harus dihormati kedua belah pihak karena merupakan kesepakatan kedua belah pihak dan kesepakatan tersebut dibuat berlaku bagi kedua belah pihak sebagai undangundang bagi yang membuatnya sesuai dengan asas pacta sunt servanda. Sehingga itikad baik sangat dikaitkan erat dengan itikad baik subyektif yaitu kejujuran seseoranng dalam melakukan perbuatan hukum dan itikad juga dapat diukur secara objektif yaitu pelaksanaan perjanjian harus sesuai dengan kepatutan pada norma-norma yang berlaku dalam masyarakat.

Asas Personalia juga dapat dijadikan salah satu asas perjanjian BOT ini dimana Pasal 1315 KUHPer yang menyatakan bahwa "pada umumnya tak seorangpun dapat mengikatkan diri atas nama diri sendiri atau meminta ditetapkan suatu janji daripada untuk dirinya sendiri” dan Pasal 1340 KUHPer "perjanjian-perjanjian hanya berlaku antara para pihak-pihak yang membuatnya. Perjanjian ini tidak dapat membawa rugi kepada pihak-pihak ketiga; tak dapat pihak-pihak ketiga mendapat manfaat karenanya, selain hal yang diatur dalam Pasal 1317." Oleh karena itu menurut penulis bahwa tidak

\footnotetext{
${ }^{14)}$ Anita, Bangun Guna Serah (Build Operate and Transfer/BOT) Membangun Tanpa Harus Memiliki Tanah(Perspektif Hukum Agraria, Hukum Perjanjian, dan Hukum Publik). Cetakan ke-1, (Bandung: Keni Media, 2013),101.
} 
tepat jika pihak PT Sarana Pembangunan Palembang Jaya menarik pihak ketiga yaitu Dinas Penerangan Jalan, Pertamanan, dan Pemakaman Kota Palembang untuk ikut bertanggung jawab akan ganti rugi akibat dari perbuatan hukum yang dilakukannya yaitu pemutusan perjanjian secara sepihak meskipun pemegang hak atas tanah dalam hal ini juga merupakan anak usaha pemerintahan maka masih berhubungan dengan dinas-dinas pemerintahan setempat.

Perjanjian BOT menurut Pasal 1 Keputusan Menteri Keuangan RI Nomor 248/KMK.04/1995 tentang Perlakuan Pajak Penghasilan terhadap Pihak Pihak yang Melakukan Kerjasama dalam Bentuk Perjanjian Bangun Guna Serah (BOT) bahwa Bentuk perjanjian kerjasama yang dilakukan antara pemegang hak atas tanah dengan investor, yang menyatakan bahwa pemegang hak atas tanah memberikan hak kepada investor untuk mendirikan bangunan selama masa perjanjian bangun guna serah (BOT), dan mengalihkan kepemilikan bangunan tersebut kepada pemegang hak atas tanah selama masa bangun guna serah berakhir. Maka perjanjian BOT harus memenuhi 3 aspek sesuai dengan konsep nya yaitu adanya pembangunan, adanya adanya pengoperasian (bisa dilakukan satu pihak atau kedua belah pihak tergantung pada perjanjian), dan adanya pengembalian hak pakai atas tanah beserta bangunan setelah nilai komersiil dari tanah dan bangunan tersebut telah habis masa pengunaannya. Dan setelah mempelajari kasus posisi di atas berdasarkan putusan maka penulis mencoba menganalisis apa akibat hukum dari pembatalan perjanjian secara sepihak tersebut yang dilakukan oleh pemegang hak atas tanah. Jika dilihat bahwa tanggal sejak dari perjanjian tersebut disepakati yaitu tanggal 16 Mei 2011 dan kemudian terjadi pemutusan hubungan kerjasama dengan keluarnya surat Pemberitahuan Pemutusan Perjanjian Kerjasama Nomor 323/SP2J-PPKS/VI/2012 pada bulan juni 2012 maka tuduhan mengenai tidak adanya keseriusan dari pihak investor dalam menjalankan kewajibannya tentu sangat tidak berdasar. Apalagi seperti yang telah tertulis dalam putusan bahwa pihak investor telah melakukan pembongkaran gedung lama lalu membuat desain dan arsitektur, menyediakan 
bahan bangunan, dan biaya gaji pegawai wages juga telah digelontorkan tentu sangatlah tidak berdasar di dalam rekonvensi yang diajukan oleh pihak pemegang hak atas tanah yang menyatakan bahwa pihak investor tidak ada itikad baik untuk melaksanakan kewajibannya. Dan hal tersebut membuat perjanjian BOT yang berlandaskan pada asas kerjasama yang saling menguntungkan ${ }^{15)}$ menjadi tidak terpenuhi. Apalagi di dalam perjanjian tersebut rupanya tidak diatur secara jelas dan spesifik mengenai tata cara pembatalan perjanjian serta deadline waktu pembangunan yang harus diselesaikan secara tuntas untuk jangka waktu berapa lama. Di dalam perjanjian hanya mengatur bahwa jika terjadi suatu permasalahan maka akan diselesaikan lewat BANI cabang palembang. Dan hal tersebut pun nyatanya tidak dilakukan oleh pihak pemegang hak atas tanah dalam hal ini BUMD tersebut tetapi langsung mengeluarkan surat peringatan 4 kali lalu pemberitahuan pemutusan hubungan kerjasama. Dan akan lebih baik menurut penulis penyelesaian permasalahan yang timbul dalam perjanjian BOT diselesaikan dengan jalan musyawarah akan lebih baik karena akan menyelesaikan suatu solusi yang lebih bagus daripada harus dibawa ke pengadilan. Tetapi untuk kasus yang terjadi antara PT Sarana Pembangunan Palembang Jaya dengan PT Tradeways Internasional karena tidak adanya musyawarah terlebih dahulu dan langsung terjadi pemutusan hubungan perjanjian maka akan lebih baik dibawa ke dalam jalur pengadilan agar sebagai investor lebih mendapat kepastian hukum dan hak dari investor dapar terpenuhi kembali. Jika dilihat dari kewajiban yang dilakukan investor seperti membongkar gedung lama, membuat gambar arsitek, serta mempersiapkan bahan bangunan penulis dapt menyimpulkan bahwa investor sudah bekerja dengan baik dalam waktu satu tahun bahkan sudah memenuhi prestasi tetapi PT Sarana Pembangunan Palembang Jaya selaku pemegang hak atas tanah dalam putusan tetap kekeh beralasan dalam rekonvensi-nya bahwa pihak investor tidak serius dalam melakukan investasi dan terkesan terlantar padahal dalam putusan sudah disebutkan oleh pihak investor bahwa di dalam adendum

\footnotetext{
${ }^{15)}$ Irawan Soerojo, Op.Cit., 60.
} 
perjanjian tidak terdapat pengaturan secara rinci kapan habis waktu pengerjaan untuk pembangunan.

Berdasarkan KUHPer Pasal 1365 KUHPer yang berbunyi setiap perbuatan melawan hukum yang oleh karenanya menimbulkan kerugian pada orang lain yang karena kesalahannya menyebabkan kerugian itu menggani kerugian. Maka perbuatan yang dilakukan oleh pemegang hak atas tanah adalah masuk dalam kategori perbuatan melawan hukum yang sangat merugikan pihak investor sehingga pihak pemegang hak atas tanah wajib untuk membayar ganti kerugian yang dialami oleh pihak investor. Sehingga Pada prinsipnya ada tiga hal mendasar yang menyebabkan seseorang secara hukum harus bertanggungjawab membayar nilai ganti rugi, diantaranya :

1. karena kesalahan orang tersebut (Pasal 1365 KUHPer);

2. karena kelalaian orang tersebut (Pasal 1366 KUHPer);

3. karena pertanggungjawaban tersebut telah diatur dengan undang-undang. Dari ketiga hal tersebut, perbedaan dasar tanggungjawab yang akan timbul. Secara garis besar dihasilkan tidak jauh berbeda, yaitu diakui atau tidaknya kewajiban untuk mengganti kerugian. ${ }^{16)}$

Pernyataan wanprestasi yang diajukan dalam rekonvensi oleh pihak PT Sarana Palembang Pembangunan Jaya. Bahwa adakalanya salah satu pihak di perjanjian tersebut belum bisa memenuhi perjanjiannya. Oleh karena itu dalam menilai seseorang telah melakukan wanprestasi atau tidaknya kadang terdapat kesulitan karena terutama untuk proses pembangunan sebuah proyek harus memerlukan ijin-ijin tertentu yang tentu sudah kita ketahui bersama bahwa ijin tersebut lama prosesnya. Misalnya di dalam kasus ini saja proses pembongkaran bangunan tanpa ada IMB (Ijin Mendirikan Bangunan) dijadikan salah satu dalil pemutusan hubungan perjanjian padahal PT Sarana Pembangunan Palembang Jaya sebagai salah satu BUMD membantu proses tersebut agar target pembangunan cepat tercapai. Karena BUMD merupakan salah satu unsur dari pemerintahan itu sendiri. Oleh karena itu penulis berpendapat bahwa bentuk kerjasama dengan pemerintahan ini sangat beresiko

\footnotetext{
${ }^{16)}$ Abdurrachman, Hukum Acara Perdata. (Jakarta: Universitas Trisakti, 2004),55.
} 
tinggi sehingga harus benar-benar diperhitungkan secara teliti dan rumit serta perjanjiannya harus dibuat sedetail mungkin karena pihak investor berhadapan dengan negara dalam kasus ini.

Baiknya perjanjian BOT ada baiknya harus memuat klausula-klausula yang jelas mengenai tata cara pemutusan hubungan perjanjian kedua belah pihak. Karena untuk benar-benar menjamin kepastian hukum maka peraturan perundang-undangan yang berkaitan dengan BOT selain harus memenuhi persyaratan formal juga harus memenuhi persyaratan lainnya yaitu: ${ }^{17}$

1. jelas dalam perumusannya;

2. konsisten dalam perumusannya baik secara intern maupun ekstren. Konsisten secara intern mengandung makna bahwa dalam peraturan perundang-undangan yang sama harus terpelihara hubungan sistematik antara kaidah-kaidahnya, kebakuan susunan dan bahasa. Konsisten secara ekstren adalah adanya hubungan "harmonisasi" antara berbagai peraturan perundang-undangan;

3. penggunaan bahasa yang tepat dan mudah dimenegerti. Bahasa peraturan perundang-undangan haruslah bahasa yang umum dipergunakan masyarakat. Namun demikian, hal ini tidak berarti bahwa bahasa hukum tidak penting. Bahasa hukum, baik dalam arti struktur, peristilahan ataupun cara penulisan tertentu harus digunakan secara ajeg karena merupakan bagian dari upaya menjamin kepastian hukum.

Perjanjian BOT juga biasanya terdapat pembagian hak dan kewajiban serta tanggungjawab masing-masing pihak. Ketentuan tersebut biasanya berisi sanksi sekaligus apabila salah satu pihak lalai memenuhi kewajiban atau tanggungjawabnya yang disebut dengan klausula mengenai wanprestasi. Wanprestasi adalah suatu peristiwa dimana debitur tidak memenuhi kewajiban prestasi perikatannya dengan baik, dan debitur mempunyai unsur salah atas tidak memenuhinya prestasi tersebut. ${ }^{18)}$

\footnotetext{
${ }^{17}$ Anita, Op.Cit., 135.

18) J.Satrio, Wanprestasi Menurut KUHPerdata, Doktrin, dan Yurisprudensi, (Bandung: Citra Aditya Bakti, 2012), 35.
} 
Menurut Subekti ada beberapa alasan yang dapat digunakan oleh pihak yang wanprestasi :

a. karena keadaan memaksa;

b. bahwa kreditur sendiri juga belum sepenuhnya melunasi seluruh kewajibannya kepada debitur (exceptio non adempleti contractus);

c. bahwa kreditur telah melepaskan haknya untuk meminta pelaksanaan prestasi tersebut dari debitur (rechtsverwekking).

Jadi menurut penulis disini pihak investor tidak memenuhi kategori melakukan wanprestasi karena ia telah melaksanakan kewajibannya bahkan melakukan pembongkaran gedung yang lama sebelum adanya ijin dari pemerintah daerah setempat sehingga hal tersebut dijadikan sebagai salah satu alasan atau dalil oleh pihak pemegang hak atas tanah untuk melakukan pemutusan hubungan perjanjian secara sepihak.

Kasus ini proses pembongkaran dan pengeluaran biaya sudah dikeluarkan namun tiba-tiba diputus secara sepihak tentu sangat merugikan dan tidak menjamin adanya kepastian hukum bagi investor meskipun sudah ada perjanjian tetpi kalusula yang tidak lengkap mejadi suatu permasalahan apalagi dalil-dalil yang dinyatakan di dalam proses banding, kasasi, dan PK menurut penulis tidak ada dasarnya karena proses baru berjalan 1 tahun bagaimana bisa proses pembangunan sudah harus jadi dalam satu tahun. Oleh karena itu bahwa sangat patut juga pihak pemegang hak atas tanah dijatuhi hukuman untuk membayar ganti rugi karena perbuatan yang dia lakukan memenuhi unsur yang ada dalam Pasal 1365 KUHPer.

Dalam prakteknya pelaksanaan perjanjian BOT sangat rentan dengan berbagai resiko antara lain $:^{19)}$

1. Risiko politik

Hal yang dimaksud resiko politik yaitu di antaranya nasionalisasi proyek, penyelenggaraan kewajiban oleh negara, perubahan khusus dalam hukum yang merugikan proyek, kegagalan pembayaran oleh negara, kejadian overmatch yang menyangkut politik seperti kudeta atau pemogokan 
karena peraturan yang ditetapkan oleh pemerintah. Hal lainnya yang dapat dimasukkan ke dalam faktor politik adalah rencana penghentian sepihak dari pemerintah terhadap kontrak konsensi;

2. Risiko Hukum

Dapat timbul dari berbagai kemungkinan misalnya kemungkinan tidak dapat diterapkan atau tidak dapat dilaksanakannya kontrak-kontrak baik seluruhnya atau sebagian oleh para pihak;

3. Risiko ekonomi

Risiko ekonomi terjadi karena perhitungan dari proyek didasarkan pada asuransi-asuransi yang tidak benar dan bias terhadap biaya implementasi proyek, keadaan pasar, atau pergerkan nilai mata uang yang tiba-tiba melonjak sehingga keadaan tersebut menyulitkan pihak investor untuk melanjutkan pelaksanaan perjanjian BOT;

4. Risiko keadaan memaksa

Misalnya terjadi perang, huru hara yang mempengaruhi daripada pelaksanaan BOT sehingga tidak mungkin untuk diteruskan;

5. Faktor pasar dan pendapatan

Yaitu hilangnya pendapatan yang disebabkan oleh ketidakcukupan pendapatan langsung dari proyek kekurangan pendapatan dari sumber lain yang berkaitan dengan proyek, atau pembatasan oleh pemerintah dalam hal peningkatan tarif atau jangka waktu penggunaan minim dari proyek.

Menurut pendapat penulis dalam kasus ini pemutusan perjanjian secara sepihak terjadi karena resiko politik karena perjanjian baru mau berjalan satu tahun tetapi sudah diputus perjanjiannya oleh BUMD terkait.

Alangkah lebih baiknya jikalau penyelesaian sengketa dalam perjanjian BOT diawali dengan musyawarah mufakat terlebih dahulu agar mendapat penyelesaian dan solusi terbaik bagi pihak-pihak terkait. Dan apabila seperti kasus ini tidak ada kepastian hukumnya lagi maka lebih baik dibawa ke jalur pengadilan setempat yang berwenang agar hak-hak kedua belah pihak terjamin dan terpenuhi meskipun dalam perjanjian BOT ini ada klausa yang mengatur di 
Pasal 11 huruf (B) tentang penyelesaian perselisihan bahwa "Jika dalam hal di atas para pihak tidak dapat mencapai persetujuan, maka para pihak akan menyelesaikannya melalui Badan Arbritase Nasional Indonesia (BANI) Cabang Palembang”. Dan dalam kenyataannya pun sekarang Taman Kambang Iwak Besak tersebut dikekola oleh Bank Sumsel sebagai taman kota yang gratis sehingga dapat disimpulkan bahwa hal tersebut sangat tidak menjamin adanya suatu kepastian hukum meskipun ada perjanjian tertulis dan putusan pengadilan yang mewajibkan ganti rugi tetapi menurut asumsi penulis ganti rugi tersebut masih belum dibayarkan oleh pihak BUMD, hal tersebut dibuktikan yaitu dengan adanya proses Peninjauan Kembali yang dilakukan oleh PT Sarana Pembangunan Palembang Jaya.

Berdasarkan Pasal 1267 KUHPer "pihak yang terhadapnya perikatan tidak dipenuhi, dapat memilih, memaksa pihak lain untuk memenuhi perjanjian. Jika hal itu masih dapat dilakukan atau menuntut pembatalan perjanjian dengan penggantian biaya, kerugian, dan bunga." Menurut kajian penulis berdasarkan Pasal 1267 KUHPer jika pihak pemegang hak atas tanah merasa investor membuat Taman Kambang Iwak Besak tersebut terbengkalai dan adanya wanprestasi harusnya ia dapat memaksa investor untuk meminta melaksanakan prestasi, meminta pelaksanaan dengan ganti rugi, meminta ganti rugi, melakukan pemutusan pembatalan perjanjian timbal balik, dan meminta pemutusan perjanjian timbal balik dengan ganti rugi tetapi harus sesuai dengan syarat yang ada dalam Pasal 1266 KUHPer agar tidak menjadi suatu perbuatan melawan hukum. tetapi penulis sangat setuju dengan pendapat Dr. Atalim S, S.H.,M.H. bahwa asas asas kebebasan berkontrak menjadi tidak berlaku lagi apabila dihadapkan dengan kepentingan umum karena banyak sekali kasus dimana BUMD dan Pemerintah yang berkomitmen dalam suatu perjanjian BOT tetapi secara tiba-tiba melakukan pembatalan perjanjian secara sepihak. Oleh karena itu akan lebih baik jika seorang investor berhadapan dengan pemerintah dalam komitmen suatu perjanjian, perjanjiannya harus dibuat sedetail mungkin agar tidak ada kesewenang-wenangan dalam pemutusan perjanjiannya sehingga mengakibatkan kerugian bagi pihak investor. 
Sedangkan pihak investor telah mempersiapkan segala sesuatu untuk pembangunan dan telah mengeluarkan banyak dana untuk melakukan pembangunan mulai dari persiapan perjanjian, pengeluaran untuk penyediaan bahan bangunan serta rancangan infrastruktur.

Berdasarkan wawancara dengan Dr. Endang Pandamdari, S.H., cn., M.H. menyatakan bahwa ketentuan tata cara pemutusan perjanjian memang diatur dalam Pasal 1266 KUHPer tetapi hal tersebut dapat dikesampingkan dengan kesepakatan kedua belah pihak. Menurut penulis untuk perjanjian BOT dengan nilai investasi tinggi dan resiko yang tinggi di tangan investor, penulis tidak setuju dengan mengesampingkan Pasal 1266 KUHPer karena apabila dikesampingkan maka di kemudian hari dapat memicu terjadi pembatalan perjanjian tanpa putusan pengadilan yang belum tentu pihak yang dilakukan pemutusan perjanjian tersebut melakukan wanprestasi terhadap perjanjian. Hal tersebut tentu akan sangat merugikan salah satu pihak terutama pihak investor.

Oleh karena itu menurut penulis bahwa akibat hukum yang dijatuhkan oleh hanya ganti rugi secara materiil tidak sesuai dengan biaya dan waktu yang sudah dikeluarkan oleh pihak investor dari mulai terjadinya proses pengehentian pembangunan sampai kepada adanya upaya hukum yang masih terus dilakukan sehingga tidak adanya kepastian. Upaya-upaya hukum yang dimaksud adalah upaya hukum oleh pihak pemegang hak atas tanah agar lepas dari kewajiban ganti rugi yang ditetapkan oleh putusan hakim sampai pada upaya Peninjauan Kembali yang terakhir yaitu menarik pihak ketiga agar ikut serta melaksanakan kewajiban ganti rugi yang diputuskan oleh hakim. Oleh karena itu bagi calon investor yang ingin melakukan kerjasama investasi ke dalam bentuk perjanjian BOT, akan lebih baik jika setiap klausula hak dan kewajiban diatur secara rinci, jelas, dan spesifik agar apabila terjadi sengketa di kemudian hari, kerugian yang dialami dapat diminimalisir apalagi di dalam studi kasus yang dijadikan contoh ini pembangunan tersebut sudah berjalan dan pihak investor sudah mulai melakukan investasi di atas tanah tersebut. Sedangkan pemegang hak atas tanah seharusnya sebelum melakukan pemutusan perjanjian dikaji terlebih dahulu karena kemungkinan hal tersebut 
akan berdampak pada investor yang akan jera pada kemudian hari untuk melakukan investasi di atas tanah pemegang hak atas khususnya dalam kasus ini yaitu tanah milik pemerintah daerah yang dikelolah oleh Badan Usaha Milik Daerah.

\section{Penutup}

Berdasarkan permasalahan yang diuraikan, maka dapat disampaikan suatu saran dan kesimpulan dan saran yaitu sebagai berikut :

\section{A. Kesimpulan}

Akibat hukum dari pembatalan perjanjian secara sepihak oleh pemegang hak atas tanah berdasarkan Putusan No. 97 PK/Pdt/2017 ialah kewajiban ganti rugi yang ditetapkan oleh putusan hakim. Tetapi ganti rugi tersebut menurut penulis masih belum adil karena dari semua gugatan yang diajukan investor hanya dikabulkan sebagian saja yaitu PT Sarana Palembang Pembangunan Jaya wajib untuk menjalankan perjanjian seperti semula dan ganti kerugian materiil yang dikabulkan sebesar Rp 4.413.000.000 (empat milyar empat ratus tiga belas juta rupiah) tetapi tuntutan yang lain seperti kerugiaan imateriil dan sita jaminan tidak dikabulkan oleh hakim.

\section{B. Saran}

Bagi hakim yang memutus perkara ini hendaknya lebih bijaksana dalam memutus perkara dan mengabulkan semua tuntutan investor karena perbuatan melawan hukum yang dilakukan oleh pihak pemegang hak atas tanah sangat merugikan dari segi materiil dan imateriil. Pihak investor dalam melakukan kerjasama dalam bentuk perjanjian BOT sebaiknya setiap pengaturan klausula perjanjian diatur lebih rinci dan spesifik lagi agar tidak terjadi kasus seperti ini lagi.

\section{DaftarPustaka}




\section{A. Buku}

Abdurrachman, HukumAcaraPerdata. (Jakarta: Universitas Trisakti, 2004).

Anita, Bangun Guna Serah (Build Operate and Transfer/BOT) Membangun Tanpa Harus Memiliki Tanah(Perspektif Hukum Agraria, Hukum Perjanjian, dan Hukum Publik). Cetakan ke-1, (Bandung: Keni Media, 2013).

Bambang Sunggono, Metodologi Penelitian Hukum, Cetakan ke-6. (Jakarta: RajaGrafindo Persada, 2003).

IrawanSoerodjo, Hukum Perjanjian dan Pertanahan Perjanjian Build, Operate, and Transfer (BOT) atas tanah Pengaturan, Karakteristik, dan Praktik, cetakan ke -2, (Yogyakarta: Laksbang PRESSindo 2017).

J.Satrio, Wanprestasi Menurut KUHPerdata, Doktrin, dan Yurisprudensi, (Bandung: Citra Aditya Bakti, 2012).

Munir Fuady, Sejarah Hukum, (Bogor: Ghalia Indonesia, 1982).

Moch. Isnaeni, "Perkembangan Hukum Perdata di Indonesia,"Asas Proposionalitas dalam Kontrak Bisnis, ed. Agus Yudha Hernako(Yogyakarta: Laksbang Grafika, 2013).

Peter Mahmud Marzuki, Penelitian Hukum, Cetakan ke-4, (Jakarta : Kencana Prenanda Media Group,2008).

Soerjono Soekanto dan Sri Mamudji (2), Penelitian Hukum Normatif, Cetakan ke-7, (Jakarta: Raja Grafindo Persada, 2004).

\section{B. Peraturan}

Indonesia, Kitab Undang-undang Hukum Perdata

Indonesia, Keputusan Menteri Keuangan RI Nomor 248/KMK.04/1995 tentang Perlakuan Pajak Penghasilan terhadap Pihak Pihak yang Melakukan Kerjasama dalam Bentuk Perjanjian Bangun Guna Serah (BOT),

Indonesia, Peraturan Menteri Dalam Negeri Republik Indonesia Nomor 19 tahun 2016 tentang Pedoman Pengelolaan Barang Milik Daerah 

(Studi Kasus : Putusan No.97/PK/PDT/2017) 